\begin{tabular}{|c|c|}
\hline 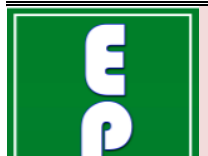 & $\begin{array}{c}\text { International Journal of Current Research } \\
\text { and Academic Review }\end{array}$ \\
\hline 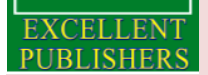 & $\begin{array}{c}\text { ISSN: 2347-3215 (Online) } ;, ; \text { Volume 5 ,; Number } 2 \text { (February-2017) } \\
\text { Journal homepage: http://www.ijcrar.com }\end{array}$ \\
\hline
\end{tabular}

doi: http://dx.doi.org/10.20546/ijcrar.2017.502.011

\title{
Distribution and Proximate Compositions of Dry Season Browses in Adamawa State, North-Eastern Nigeria
}

\author{
I.H. Kubkomawa ${ }^{1 *}$, C.C. Achonwa ${ }^{2}$, U.E. Ogundu ${ }^{2}$, I.C. Okoli ${ }^{2}$, and A.B.I. Udedibie ${ }^{2}$ \\ ${ }^{I}$ Department of Animal Health and Production Technology, the Federal Polytechnic, P.M.B. 35 Mubi, Adamawa \\ State, Nigeria \\ ${ }^{2}$ Department of Animal Science and Technology, Federal University of Technology, P. M.B. 1526 Owerri, Imo State, \\ Nigeria \\ *Corresponding author
}

\begin{abstract}
Pastoralists in the semi-arid zones of north-eastern Nigeria utilize diversities of browse trees to augment dry season ruminant feeding because of poor feed resource availability during the period. Primary data generated from 300 pastoralists surveyed across Mubi north, Gombi and Jada LGAs of Adamawa state were used to determine the commonly browsed trees in the state during the dry season period. Thereafter, proximate compositions of leaf meals from five most preferred dry season browses among these were determined in order to estimate their nutrient values. Ten commonly utilized browse plants were identified as being utilized in each of the LGAs, with Balanite aegyptica, Khaya senegalensis, Tamarinae indica, Panicum maximum and Mangifera indica being the most preferred by pastoralists in the area. Crude protein content of the leaf meals of these preferred plants ranged from the $9.35 \%$ recorded in $P$. maximum to $16.73 \%$ in $T$. indica, while ether extract values ranged from the $2.89 \%$ recorded in $P$. maximum to $6.72 \%$ in $K$. senegalensis. The leaf meals were moderate in their crude fibre, with $K$. senegalensis recording $23.53 \%$, while $P$. maximum recorded $32.50 \%$. Ash values were high with mean values standing at $10.41 \pm 1.97 \%$ and $M$. indica recording the highest value of $13.25 \%$. These findings support the value placed on these plants by pastoralists as dry season feed resources. There is the need to promote extensive planting of these cherished browse species in the study area in order to provide the needed dry season feed resources to livestock, while limiting the frequent cutting of other tree species by the pastoralists; a habit that leads to deforestation and dwindling forest resources in the zone.
\end{abstract}

\section{Article Info}

Accepted: 25 January 2017

Available Online: 20 February 2017

\section{Keywords}

Browses plants, Pastoralists, Semi arid zone.

\section{Introduction}

The feed resources of pastoralist cattle consists mainly of grasses, legumes, browses, and crop residues indigenous to the production zones and have been reported to be of low yield and quality (Shiawoya and Tsado, 2011; Nweze et al., 2012). Good quality forage is available in adequate amounts to support reasonable level of cattle production from early to late rainy seasons, while at other times, pasture and range plants decline in quantity and quality 
(Moutari, 2008). During the dry season period, available natural pastures are low in protein, nitrogen, sulphur, vitamins and other nutrients, while fibre is high with dry matter content of more than 30\% (Bonsi et al., 1991; Hughes et al., 2011).

The best way to evaluate feed quality is animal performance while intake, digestibility and efficiency of utilization are characteristics of feed that determine animal performance (Mertens, 1994). Chemical property of feed that have been linked with intake and digestibility are fibre, lignin and protein which are used increasingly to predict animal performance (Cherney and Mertens, 1998). Therefore, a systematic chemical characterization of feed for cattle must include determination of fibre, lignin, protein and critical to this is an accurate dry matter (DM) content determination (Adegbola, 1985 and Alhassan et al., 1987).

To consolidate this assertion, Okoli et al. (2003) stated that, proximate analysis of feed is specifically useful, in screening the array of tropical browse plants utilized by indigenous farmers for ruminant feeding. Also earlier research has shown that, chemical analysis of feed provides valuable information about the actual chemical constituents influencing digestion (Van Soest, 1994). The objectives of the study were to survey the distribution and evaluate proximate composition of the most cherished browses for cattle production during the dry season in Adamawa State, North-Eastern Nigeria.

\section{Materials and Methods}

\section{Study area}

Adamawa State is located at the area where the River Benue enters Nigeria from Cameroon Republic and is one of the six states in the North-East geopolitical zone of Nigeria. It lies between latitudes $7^{0}$ and $11^{\circ}$ North of the Equator and between longitudes $11^{\circ}$ and $14^{\circ}$ East of the Greenwich Meridian (Mohammed,1999). It shares an international boundary with the Republic of Cameroon to the east and interstate boundaries with Borno to the North, Gombe to the North-West and Taraba to the West and South (ASMLS, 2010a), as can be seen in figure 1.

The State has minimum and maximum rainfall of 750 and $1050 \mathrm{~mm}$ and an average minimum and maximum temperature of $15^{\circ} \mathrm{C}$ and $32^{\circ} \mathrm{C}$, respectively. The relative humidity ranges between 20 and $30 \%$ with four distinct seasons that include: early dry season (October -
December); late dry season (January - March); early rainy season (April - June) and late rainy season (July September) (Adebayo, 1999). The vegetation type is best referred to as guinea savannah (Areola, 1983;Adebayo and Tukur, 1997). The vegetation is made up of grasses, aquatic weeds along river valleys and dry land weeds inter-spaced by shrubs and woody plants. Plant heights ranges from few centimeters (Short grasses) to about one meter tall (tall grasses), which form the bulk of animal feeds.

Cash crops grown in the state include cotton and groundnuts, sugar cane, cowpea, benni seed, bambara groundnut, tiger nut, while food crops include maize, yam, cassava, sweet potatoes, guinea corn, millet and rice. The village communities living on the banks of rivers engage in fishing, while the Fulani and other tribes who are not resident close to rivers are pastoralists who rear livestock such as cattle, sheep, goats, donkeys, camels, horses and poultry for subsistence (Adebayo and Tukur, 1997; Adebayo, 1999).

\section{Study site}

Three Local Government Areas, one from each of the three senatorial districts in the state were chosen for the study. The Local Government Areas were purposively selected to cut across the State which represents the pastoral zones with higher number of cattle producers in the State (Adebayo, 1999). The study areas include Mubi North (Northern Senatorial Zone), Gombi (Central Senatorial Zone) and Jada LGAs (Southern Senatorial Zone) as shown in figure 2.

\section{Data collection}

The study was carried out between 2013 and 2014 and identification of browse trees were done by questionnaires, interview, kraal visits and direct field observation for at least two hours in the morning during grazing. About 500mg samples each of 10 most cherished browse resources from each location were collected and used for proximate analysis. The browse species were identified with the assistance of a botanist using Hausa, English and botanical names at the Department of Botany, Adamawa State University, Mubi and samples were deposited in the University herbarium.

(a) Dry matter (DM) content: The browses identified as being dry season feed resources for cattle were collected 
fresh. The fresh samples were dried inside the Laboratory for 4 - 5 days to avoid lose of some nutrients. After drying, the samples were ground to gritty powder using muter and passed through a $1 \mathrm{~mm}$ sieve. A quantity of $0.5 \mathrm{Kg}$ of each sample was preserved inside a sealed tube, labeled and stored for subsequent proximate analysis. Feed samples were analyzed for dry matter content in accordance with the methods of Association of the Official Analytical Chemists (AOAC, 1995; AOAC, 2004). Dry matter content for each sample was determined by oven-drying $3 \mathrm{~g}$ at $105^{\circ} \mathrm{C}$ for 24 hours.

(b) Crude protein (CP): Samples of the feeds were analyzed for nitrogen (crude protein) in accordance with the Kjeldahl method (AOAC, 1995). Crude protein were determined by measuring the nitrogen content of the feed and multiplying it by a factor 6.25 .

(C). Ash: About 3 grammes of each of the samples were analyzed for ash determination by complete combustion at $550^{\circ} \mathrm{C}$ in a furnace for 3 hours according to the methods of Association of the Official Analytical Chemists (AOAC, 1995; AOAC, 2004).

(d) Fiber: Fibre was analyzed by the trichloroacetic acid (TCA) digestion as described in the methods of Association of the Official Analytical Chemists (AOAC, 1995; AOAC, 2004).

(e) Ether extract: Ether extract was determined by dry soxhlet method for fat extraction as stated in the methods of the Association of the Official Analytical Chemists (AOAC, 1995; AOAC, 2004).

(f) Nitrogen Free Extract (NFE): NFE was obtained by subtracting the sum of percentages of all the nutrients already determined from 100 . That is by using the formular \% NFE =

$\mathrm{DM}-(\% \mathrm{Ash}+\% \mathrm{CF}=\% \mathrm{EE}+\% \mathrm{CP})$.

(g) Detergent System of Fiber Analysis (NDF, ADF and ADL): This system was developed by Van Soest et al. (1991), and so is also referred to as the Van Soest system. This method separates cell contents from cell wall constituents which consist of hemicelluloses, cellulose, lignin and heat damaged protein.

(i) Neutral Detergent Fiber (NDF): This was carried out by boiling a sample of dry forage feed and refluxed in a neutral detergent solution (consisting of sodium lauryl sulphate, disodium dihydrogen ethylene amine tetra-acetate and phosphate buffer) after which, soluble carbohydrates, proteins and fats were extracted as described by Van Soest et al. (1991). The residue, which is mainly hemicelluloses, cellulose and lignin are components of the plant cell wall and is referred to as "neutral detergent fiber" (NDF).

(ii) Acid Detergent Fiber (ADF): This was also carried out by boiling a sample of dry forage feed and refluxed in an acidified detergent solution (consisting mainly of cetyl trimethylammonium bromide in sulphuric acid); soluble carbohydrates, proteins, fats and hemicelluloses are extracted into solutionas described by Van Soest et al. (1991). The residue, which is mainly cellulose and lignocelluloses is referred to as "acid detergent fiber" (ADF).

(iii) Acid Detergent Lignin (ADL or lignin): Percentage acid detergent lignin (ADL) or lignin content was obtained by finding the differences between NDF and ADF values as described by Church (1991). However, van Soests' detergent method also provides a means of determining cellulose and lignin by digesting the ADF with $72 \% \mathrm{H}_{2} \mathrm{SO}_{4}$.

\section{Data analysis}

All survey data generated in this study were subjected to descriptive statistics such as frequencies and percentages.

\section{Results and Discussion}

\section{Browse tree resources distribution during dry season in Adamawa State}

The results of this study revealed 10 common tree browses that serve as dry periods feed resources in the study locations (Table 1). The results support the report of Okoli et al. (2003) that, there is an abundance of tropical browse plants available to ruminants in Nigeria. Earlier reports by Olayemi et al. (1998) and Omokaye et al. (2001) have also highlighted the available browse resources in Nigeria, while Opara (1996) and Oji and Isilebo (2000) reported that, such browse plants provide the vitamins and mineral elements, which are frequently lacking in grassland pastures. Their year round evergreen presentation and nutritional abundance provides for year round provision of fodder. The diversity and distribution of browse plants of Northern Nigeria have also received 
attention in studies carried out in the North (Saleem et al., 1979) and Middle Belt (Ibeawuchi et al., 2002) of Nigeria. Odoh and Adamu-Noma (2000) stated that, browses enable standing feed reserve to be built so that herds can survive critical periods of shortfall, or even prolonged periods of drought, without remarkable weight losses.

In recent time however, deforestation, urbanization and bush burning have become major factors responsible for dwindling proceeds of browse feed resources for ruminant livestock, especially in Northern Nigeria. For example, according to Yahya et al. (2000), traditional herdsmen and other pastoral groups habitually cut down branches from various trees species such as Acacia, Adamasonia and Ficus spp, making them available to livestock during the dry season, when no other forage is available. Browse plants, beside grasses, constitute one of the cheapest sources of feed for ruminants.

Many browse species have chemicals that appear to be produced for the purpose of deterring invasion or consumption of their leaves by microbes, insects and herbivorous animals (Njidda, 2010). However, Gidado et al. (2013), in their study of anti-nutritive factors and nutrient composition of some selected browse plants used as livestock feeds in neighboring Taraba State, reported that, the effects of high protein forage could over-ride the effect of the toxic compounds when used as supplement in the diets.

\section{Proximate composition of the most preferred browses 6} during dry season in Adamawa State

It has been observed from this study that adequate nutrient supply, as a factor of production is a major constraint to cattle productivity in the study area. The proximate composition (\%) of the most preferred browses during dry season are shown in table 2. The results showed mean DM content of the most preferred browses during dry season was $89.78 \pm 3.99 \%$ with the range of 84.90 to $94.24 \%$ as presented in table 2 . The Balanite aegyptica with $84.90 \% \mathrm{DM}$ and therefore $15.10 \%$ moisture content was not properly dried and grow mold if stored for extended period. The results however fell within the reference values for tropical browse trees and agree with Gidado et al. (2013), who reported similar mean dry matter (MDM) content of some browse species in Taraba State to be $86.97 \%$. These values are much higher than the mean dry matter value of $65.1 \%$ reported by Carew et al. (1980) for browse plants in the derived savannah area of Nigeria.
The mean crude protein of the preferred browse plants was $13.96 \pm 3.08 \%$ with a range of $9.35-16.73 \%$. Khaya senegalensis had the highest $\mathrm{CP}$ of $16.73 \%$ followed by Tamarinae indica with $16.50 \%$, while the least was recorded by Panicum maximum (9.35\%) which actually is a grass but was selected by the farmers for unknown reasons. Therefore, all browse plants have a reasonable quantity of crude protein which can be used in cattle production. The results agree with that of Njidda (2010), who reported similar $\mathrm{CP}$ content of semi-arid browse forages of North-Eastern Nigeria. Omoniyi et al. (2013) also reported $P$. maximum a tropical natural grass in humid and sub humid regions of Nigeria to have $9.27 \%$, while $M$. aegyptia was reported to yield $19.63 \% \mathrm{CP}$. Norton (2003) also justifies the use of browse forages in small quantities in order to supplement poor quality pastures and crop residues.

The mean crude fiber content of the browses was $26.93 \pm 3.45 \%$. Panicum maximum recorded the highest crude fibre (CF) content of $32.50 \%$ followed by Mangifera indica with $27.46 \%$, while Khaya senegalensis had the lowest CF of $23.53 \%$. The crude fiber content of the various browse plants is within the range of $15-20 \%$ CF recommended for improved intake and production in finishing ruminants since it represents insoluble carbohydrate such as alkali insoluble lignin, fibre bound Nitrogen and cellulose (Buxton, 1996).

The results of mean ether extract (EE) was $5.52 \pm 1.56 \%$, with Khaya senegalensis having the highest value of $6.72 \%$, followed by Balanite aegyptica with $6.71 \%$, while the lowest value of $2.89 \%$ was recorded by Panicum maximum. Ether extracts content of browses in this study fell within the range of $4-10 \% \mathrm{EE}$ recommendation (Preston, 1995 and Campbel et al., 2006). The results agree with that of Njidda (2010), who reported a range of 2.00 to $5.00 \%$ for EE of Northeastern Nigerian browse forages. The value for all the browse species in this study are higher than the 3.0\% reported by Dibal (1991) and Ifut (1982) in semi-arid Northeastern Nigeria and for browse plants in Western Nigeria.

The mean ash value of the browse plants was $10.41 \pm 1.97 \%$, with a range of $7.74-13.25 \%$. Mangifera indica had the highest value of $13.25 \%$ followed by Khaya senegalensis with $10.70 \%$ and the least value of $7.74 \%$ was recorded by Tamarinae indica. The results agree to that of Njidda (2010), who reported a range of 8.00 to $18.00 \%$ for ash of northeastern Nigerian browse forages. Omoniyi et al. (2013) also reported that ash content in $M$. indica was higher $(13.66 \%)$ than other 
plants. In Southern part of Nigeria, Ahamefule et al. (2006), reported ash content of heavily browsed plants to be comparatively higher than values obtained in this present study. Le Houerou (1980a) and Gohl (1981) stated that the different figures obtained in the ash content of browse plants in many regions may be due to differences in oil, species and season.

The mean nitrogen free extract (NFE) was $49.66 \pm 1.87 \%$, with a range of $47.67-52.45 \%$. Panicum maximum recorded the highest value of $52.45 \%$ followed by Balanite aegyptica with $50.23 \%$, with Tamarinae indica having the least value of $47.67 \%$. These results fell within the recommended values a feed would have for livestock feeding as NFE represents the soluble carbohydrate of the feed, such as starch, sugars, pectin, organic acids, hemicelluloses and alkali-soluble lignin.

Neutral Detergent Fiber (NDF) mean value obtained from the present study (Table 2) was $48.69 \pm 9.41 \%$, with a range of $40.20-64.50 \%$. The results therefore showed that Panicum maximum had the highest value of $64.50 \%$ followed by Balanite aegyptica with $48.50 \%$, whereas Khaya senegalensis had the lowest with $40.20 \%$. The results agree with Gidado et al. (2013), who reported similar mean NDF values for the browse plants analyzed to be $48.97 \%$, higher than the as $25-45 \%$ and $20-35 \%$ reported by Le Houerou (1980b) and Norton (1994) respectively. The results, again, corroborate that of Njidda (2010), who reported fibre contents of 37.3 to $51.2 \%$ for NDF for browse forages in northeastern Nigeria.

The results Panicum maximum recorded the highest value of $39.40 \%$ followed by Mangifera indica with $34.53 \%$, while the lowest value of $19.60 \%$ was recorded by Khaya senegalensis. Mean value stood at $27.88 \pm 8.57 \%$ and agrees with Gidado et al., (2013), who reported similar $\mathrm{ADF}$ in 30 browse species to be $23.30 \%$. The results again corroborates that of Njidda (2010), who reported ADF contents of 16.2 to $41.2 \%$ for browse forages in northeastern Nigeria.

The results show that Mangifera indica recorded the highest ADL of $13.45 \%$ followed by Panicum maximum with $9.61 \%$, while the least was recorded by Tamarinae indica with $5.44 \%$. The results corroborate that of Njidda (2010), who reported 4.9 to $12.7 \%$ ADL for browse forages in northeastern Nigeria. Omoniyi et al. (2013) also reported variations in the ADL from $6.46 \%-34.53 \%$ for some browses.

Table.1 Commonly browsed tree resources during dry period

\begin{tabular}{|c|c|c|c|c|c|c|c|}
\hline S/No. & $\begin{array}{l}\text { Botanical } \\
\text { Name }\end{array}$ & $\begin{array}{l}\text { English } \\
\text { Name }\end{array}$ & $\begin{array}{l}\text { Hausa } \\
\text { Name }\end{array}$ & $\begin{array}{l}\text { Mubi } \\
\text { North }\end{array}$ & Gombi & Jada & Freq \\
\hline 1 & Acacia spp & Acacia & Madaci & + & + & + & 3 \\
\hline 2 & $\begin{array}{l}\text { Leucaena } \\
\text { leucocephala }\end{array}$ & Leucaena & & + & + & + & 3 \\
\hline 3 & $\begin{array}{l}\text { Moringa } \\
\text { oleifera }\end{array}$ & Moringa & Zoggale & + & + & + & 3 \\
\hline 4 & $\begin{array}{l}\text { Balanites } \\
\text { aegyptica }\end{array}$ & & Adua & + & + & + & 3 \\
\hline 5 & $\begin{array}{l}\text { Khaya } \\
\text { senegalensis }\end{array}$ & & & + & + & + & 3 \\
\hline 6 & $\begin{array}{l}\text { Tamarindus } \\
\text { indica }\end{array}$ & Tamarind & Tsamiya & + & + & + & 3 \\
\hline 7 & $\begin{array}{l}\text { Terminalia } \\
\text { vicenoides }\end{array}$ & & & + & + & + & 3 \\
\hline 8 & $\begin{array}{l}\text { Mangifera } \\
\text { indica }\end{array}$ & Mango & Mangoro & + & + & + & 3 \\
\hline 9 & Afzelia Africana & & & + & + & + & 3 \\
\hline 10 & Ficus polita & & & + & + & + & 3 \\
\hline Total & & & & 10 & 10 & 10 & 30 \\
\hline
\end{tabular}


Table.2 Proximate composition (\%) of the most preferred browses during dry season in Adamawa State

\begin{tabular}{llllllll}
\hline Parameters & $\begin{array}{l}B . \\
\text { egypt }\end{array}$ & $\begin{array}{l}K . \\
\text { senegalensis }\end{array}$ & $\begin{array}{l}T . \\
\text { indica }\end{array}$ & $\begin{array}{l}P . \\
\text { maxim }\end{array}$ & $\begin{array}{l}\text { M. } \\
\text { indica }\end{array}$ & Means/SD & Range \\
Proximate & Composition & & & & & \\
\hline DM (\%) & 84.90 & 88.60 & 87.64 & 93.54 & 94.24 & $89.78 \pm 3.99$ & $84.90-94.24$ \\
CP (\%) & 14.71 & 16.73 & 16.50 & 9.35 & 12.54 & $13.96 \pm 3.08$ & $9.35-16.73$ \\
CF (\%) & 26.37 & 23.53 & 24.80 & 32.50 & 27.46 & $26.93 \pm 3.45$ & $23.53-32.50$ \\
EE (\%) & 6.71 & 6.72 & 5.62 & 2.89 & 5.67 & $5.52 \pm 1.56$ & $2.89-6.72$ \\
ASH (\%) & 10.53 & 10.70 & 7.74 & 9.87 & 13.25 & $10.41 \pm 1.97$ & $7.74-13.25$ \\
NFE (\%) & 50.23 & 49.70 & 47.67 & 52.45 & 48.27 & $49.66 \pm 1.87$ & $47.67-52.45$ \\
NDF (\%) & 48.50 & 40.20 & 43.26 & 64.50 & 47.00 & $48.69 \pm 9.41$ & $40.20-64.50$ \\
ADF(\%) & 22.64 & 19.60 & 23.25 & 39.40 & 34.53 & $27.88 \pm 8.57$ & $39.40-19.60$ \\
ADL (\%) & 5.62 & 5.61 & 5.44 & 9.61 & 13.45 & $7.94 \pm 3.54$ & $5.44-13.45$ \\
HEM $(\%)$ & 25.90 & 20.60 & 20.00 & 25.90 & 12.50 & $20.98 \pm 5.50$ & $12.50-25.90$ \\
\hline
\end{tabular}

Note: Dry matter (DM); Crude protein (CP); crude fiber (CF); Nitrogen Free Extract (NFE); Neutral Detergent Fiber (NDF); Acid Detergent Fiber (ADF); Acid Detergent Lignin (ADL); Ether extract (EE);

Fig.1 Map of Nigeria showing Adamawa state, the study area in blue

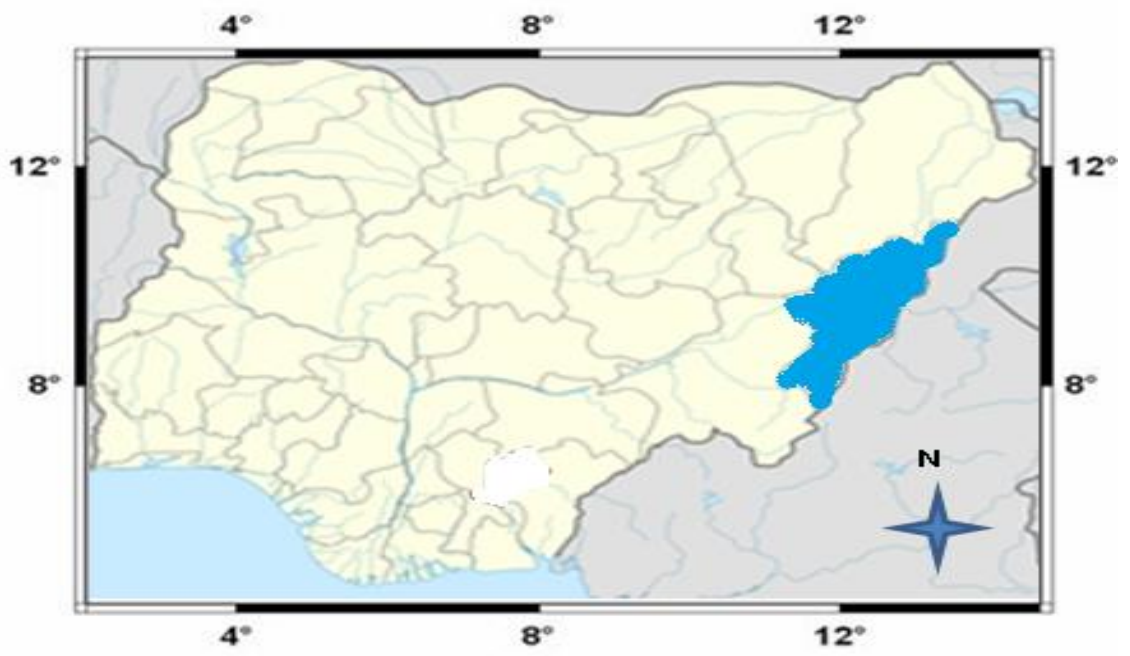

Fig.2 Map of Adamawa state showing the three study LGAs in blue

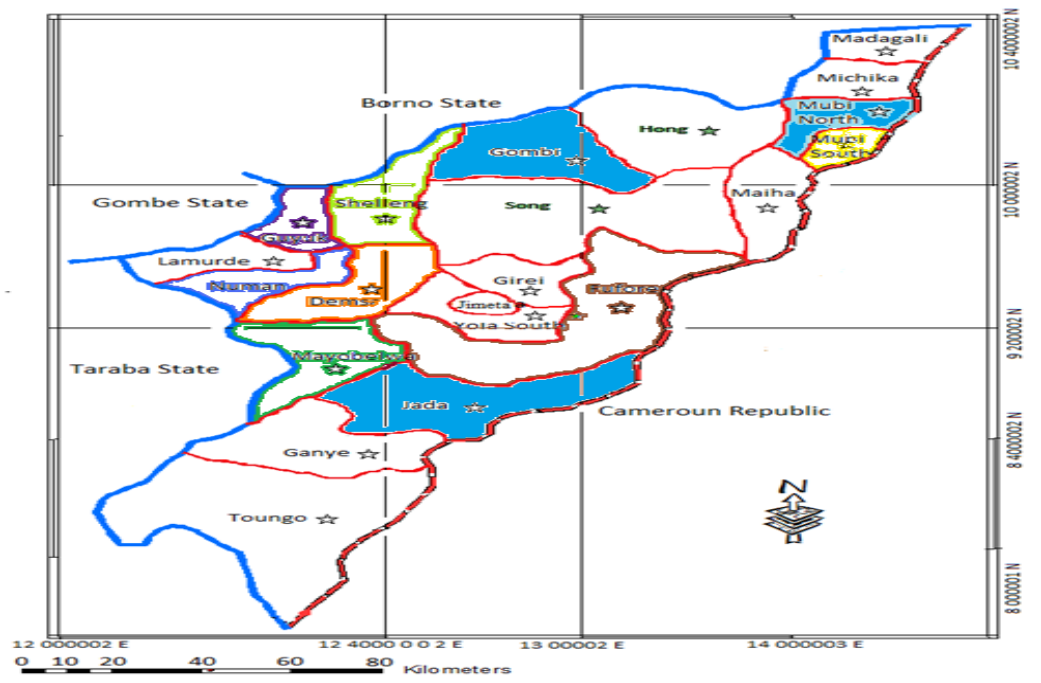


The mean hemicellulose value was $20.98 \pm 5.50 \%$, with a range of $12.50-25.90 \%$, indicating that $B$. egyptica and $P$. maxim had the highest level of digestible carbohydrates. The results again, corroborate that of Njidda (2010), who reported 4.9 to $12.7 \%$ ADL for browse forages in northeastern Nigeria.

\section{Conclusion and Recommendations}

It was observed that, adequate nutrient supply as a factor of production is the major obstacle to cattle productivity in Northern Nigeria. The situation is worse during the long dry season when animals are unable to meet their protein and energy needs from available low-quality herbage with consequent marked weight loss and productivity. The browse forages in the study area had low to moderate content of fibre. This is a positive attribute of the browse forages since the voluntary DM intake and digestibility are dependent on the cell wall constituents (fibre), especially the NDF and lignin (Bakshi and Wadhwa 2004). The availability of a variety of browses and the selection process enable cattle to extend as well as meet their feed preferences. Traditional farmers in the semi-arid region of Nigeria allow their cattle to browse on tree forages in the range lands and they cut and feed these tree foliages as supplements based on experience and convenience.

Browse plants are mostly considered alternative feed resources used by famers to support ruminant animals. All the browse plants offered to the animals, especially $B$. aegyptica, $K$. senegalensis and $T$. indica yielded higher leaf crude proteins and lower crude fibers, indicating that the browse plants could form better dry season feed resources if found in enough quantities. Feed resource conservation and storage culture should form part of our norms and values as an agrarian country who depend so much on agricultural products. Government and private stake holders should embark on massive tree planting campaign to save the zone from desert encroachment for better and quality life in general.

\section{References}

Abbator, F. I. and Kibon, A. (1999). Digestibility and Voluntary intake of some browse plants fed to sheep in the semi-arid region of Nigeria. Journal of Arid Agric., 9: $115-119$.

Adebayo, A. A. (1999). Application of agro-climatology to agricultural planning in Adamawa State. Journal of Applied Science and Management, 1: 69 - 75.
Adebayo, A. A. and Tukur, A. L. (1991). Adamawa State In maps. Department of Geography, Federal University of Technology, Yola Adamawa State. Paraclate publishing House, Yola, Nigeria, Pp. 27 - 87.

Adebayo, A. A. and Tukur, A. L. (1997). Adamawa state in maps, Pp. 8 - 45.

Adegbola, T. A. (1998). Sustainable Ruminant Production for Human Nutrition and National Development. Inaugural Lecture Series No. 7. University Inaugural Lecture Delivered on 21st January 1988 At A.T.B.U. Bauchi, Nigeria. Pp. 26 - 95.

Adegbola, T. A. (2002). Nutrient Intake Digestibility and Rumen Metabolites in Bulls Fed Rice straw with or without Supplements. Nigerian Journal of Animal Production, 29 (1): 40 - 46.

Adegbola, T.A. (1985). Browse plants: propagation management and utilization. in small ruminant production in nigeria. proceeding of the national conference on small ruminant production, Zaria, Nigeria. 6 - 10 October, 1985, NAPRI, Shika Zaria. Pp. 85-99.

Ahamefule, F. O., Obua, B. E., Ibeawuchi, J. A. and Udosen, N. R. (2006). The Nutritive Value of Some Plants Browsed by Cattle in Umudike, Southeastern Nigeria. Pakistan Journal of Nutrition, 5 (5): 404 409.

Akindele, E. O., Adeniyi, I. F. and Indabawa, I. I. (2013). Spatio-temporal assessment and water quality characteristics of Lake Tiga, Kano, Nigeria. Research Journal of Environmental and Earth Sciences, 5(2): 67-77.

Akintoye, O. A., Obi, C. N., Etim, O. A., Olorundami, T., Ukata, S. U. and Harrison, E. U. (2014). Seasonal variation in the physico-chemical characteristics of surface water in Etche river, Niger Delta Area of Nigeria. Journal of Environmental Science, Toxicology and Food Technology, 8(7): 01-07.

Alhassan, W. S. Kallah, M. S. and Bello, S. A (1987). Influence of Duration of Stay on the Field on the Chemical Composition and Nutritive Value of Crop Residues. Tropical Agriculture (TRIANDAD), 64 (1): $61-64$.

AOAC (1995). Animal feed: In official methods ofanalysis, 16th edition, AOAC (Association of Official Analytical Chemists), International Arlington VI, USA Pp. 30.

AOAC (2004). Official Method of Analysis (14th Edition) Williams S (Ed.) Association of Official Analytical Chemists, Washington DC, Pp. 152- 164

Areola, O. O. (1983). Soil and Vegetational Resources: In Ogunn, J.S; Areola, O.O and Filani, M. (Eds). Geography of Nigerian development, Heinemann Ibadan, Pp. 342. 
ASMLS (2010a). Adamawa State Ministry of Land and Survey. Map of Nigeria showing all states.

ASMLS (2010b). Adamawa State Ministry of Land and Survey. Map of Adamawa State of Nigeria showing all local government areas.

Bakshi, M. P. S. and Wadhwa, M. (2004). Evaluation of forest leaves of semi-hilly arid region as livestock feed. Asian- Australasian Journal of Animal Science, 95: 93 - 104.

Bogoro, S., Lufadeju, E. A., Adeyinka, O. A., Butswat, I. S. and Kudi, A. C. (1994). Nutritive value and utilization of crop residue based diets by Bunaji bulls. Journal of Animal Science, 14 (1and2): 49 - 58.

Boudet, A. M. (1998). A new view of lignification. Trends in Plant Science, 3: 67- 71.

Boukori, Y., Bawa, I. M. and Djaneye, B. G. (1999). Characterization of some Togo Surface waters, Bull. Chem. Soc. Ethopia, 13 (1) 11 - 21.

Breman, H. and Kessler, J. J. (1995). Woody Plants in Agro-Ecosystems of Semi-Arid Regions. Advanced series in agricultural sciences, 23: Pp. 340.

Buxton, D. R., Mertens, D. R. and Fisher, D. S. (1996). Forage quality and ruminant utilization. In: Moser, L. E., Buxton, D. R. and Casler, M. D. (eds) Cool-season Forage Grasses. American Society of Agronomy, Madison, Wisconsin, Pp. 229 - 302.

Campbell, K. L. I., Garforth, C., Heffernan, C., Morton, J., Paterson, R., Rymer, C. and Upton, M. (2006). Small Stock in Development". Natural Resources International Ltd.: Aylesford, Kent, UK.

Carew, B. A. R., Mosi, A. K. Mba, A. U. and Egbunike, G. N. (1980). The potentials of browse plants in the nutrition of small ruminants in the humid forest and derived savannah zones of Nigeria. In: H.N. LeHouerou, ed. Browse in Africa. The current state of knowledge. International Livestock Centre for Africa (ILCA). Addis Ababa, Ethiopia. Pp. 233-238.

Cherney, D. J. R. and Mertens, D. R. (1998). Modelling grass utilization for dairy cows. In: Cherney, J. H. and Cherney, D. J. R. (eds) Grass for Dairy Cattle. CAB International, Wallingford, Oxon, UK, Pp. 351.

Church, D. C. (1991). Livestock Feeds and Feeding. $3^{\text {rd }}$ Edition Prentice Hall, Eaglewood Cliffs New Jersey, UK., Pp. 456-549.

Dibal, D. B. (1991). Chemical composition and feeding values of some browse plants in the semi-arid region of North Eastern Nigeria unpublished M.Sc. thesis.

Efe, S. I., Ogban, F. E., Horsfall, M. Jnr and Akporhonor, E. E. (2005). Seasonal variations of physico-chemical characteristics in water resources quality in Western Niger Delta Region, Nigeria. Journal of applied Science and Environmental Management, 9(1): 191195.
Egila, J. N. and Nimyel, D. N. (2000). Determination or trace metals in Sediments from some Dams. Journal of Chem. Soc. Nig. 27(1): 71 -75.

Eletta, O. A. A. and Adekola, F. A. (2005). Studies of the physical and chemical properties of Asa river water, Kwara state, Nigeria. Science Focus, 10 (1): 72 - 76.

Fall, S. T. (1993). Valeur nutritive des fourrages ligneux. Leur rôle dans la complementation des fourrages pauvres des ilieux tropicaux. Thesis Doct. Univ. Sci. Tech. ENSAM, Montpellier, France, Pp. 143.

FAO.(1996). Food and agricultural organization 1996. World development report paper no. 2, Rome Italy, Pp. 51-54.

Gidado, O. G, Kibon, A., Gwargwor, Z. A., Mbaya, P. and Baba, M. J. (2013). Assessment of antinutritive factors and nutrient composition of some selected browse plants use as livestock feeds in Taraba State. International Journal of Applied Science and Engineering, 1(1): 5 - 9.

Gohl, B. (1981). Tropical feeds: Feed information summaries and nutritive value, Animal production series, FAO, Rome, Italy. Pp. $301-405$.

Ibeawuchi, J. A., Ahamefule, F. O. and Oche, J. E. (2002). An assessment of the nutritive value of the browsed plants in Makurdi, Nigeria. Nigerian Agric. Journal, 33: 128- 135.

Ibrahim, A. (2012). Linking vision with reality in the implementation of policy framework for pastoralism in Nigeria. Pastoralism: Research, Policy and Practice 2: 7.

Ifut, O. J. (1982). The chemical composition and in vitro organic digestibility of some browse in Southern Nigeria. Free comm. Abstract In: Beef production in Nigeria. NAPRI, Pp. 621.

INEC (1996). Independent National Electoral Commission political and administrative demarcation of Adamawa State.

Kibon, A. and Orskov, E. R. (1993). The use of degradation characteristics of browse plants to predict intake and digestibility by goats. Animal Production, 57: 00-00.

Kubkomawa, H. I. and Williams, B. (2010). Analyses of water supply characteristics for domestic and livestock uses in Lala District of Gombi Local Government Area, Adamawa State, Nigeria. International Journal of Tropical Agriculture and Food Systems, 6(4): 278 282.

Lawton, R. M. (1980). Browse in Micombo woodland, In: Browse in Africa, the Current state of knowledge, Le Houuerou H N (Ed.) ILCA, Addis Ababa Ethiopia, Pp. 25-31.

Le Houerou, H. N. (1980a). Browse in North Africa, In: Browse in Africa ILCA, Addis-Ababa Ethiopia, 5582. 
Le Houerou, H. N. (1980b). The role of browse in the Sahelian and Sudanian zones, in: Browse in Africa, the current state of knowledge. Addis Ababa Ethiopia.

MAFF (1984). Ministry of Agriculture, Fisheries and Food, department of Agriculture for Scotland and Department of Agriculture for Northern Ireland. Energy allowances and feeding system for ruminants. Reference Book 433, HMSO, London. Pp. 210 - 342.

Malau-Adulia, B. S., Eduvieb, L., Lakpinib, C. and MalauAdulib, A. E. O. (2004). Crop-residue supplementation of pregnant does influences birth weight and weight gain of kids, daily milk yield but not the progesterone profile of Red Sokoto goats. Reprod. Nutr. Dev., 44: $111-121$.

McDonald, P., Edwards, R. A., Greenhalgh, J. F. D. and Morgan, C. A. (1995). Animal Nutrition. Longmans group, Harlow, UK. Pp. 607.

McDowell, R. E. (1988). Improvement of crop residues for feeding livestock in smallholder farming systems. In: J. D. Reed, B. S. Capper and P. J. H. Neate (eds.). Plant Breeding and Nutritive Value of Crop Residues. Proceedings of a Workshop Held at ILCA, Addis Ababa, Ethiopia, 7-10 December 1987. ILCA, Addis Ababa. Pp. 3 - 27.

Mecha, I. and Adegbola, T. A. (1985). Chemical composition of some southern Nigeria forage eaten by goats. In: Le Houerou, H.N. (Ed). Browse in Africa; the current State of knowledge, International Livestock Centre for Africa, Addis Ababa.

Meissner, H. H., Viljoen, M. O. and van Niekerk, W. A. (1991). Intake and Digestibility by Sheep of Antherphora, Panicum, Rhodes and Smooth Finger Grass". Proceedings of the 4th International Rangeland Congress. September 1991. Montpellier, France. 648-649.

Mertens, D. R. (1994). Regulation of forage intake. In: Fahey, G. C., Collins, M., Mertens, D. R. and Moser, L. E. (eds) Forage Quality, Evaluation, and Utilization. ASA, CSSA and SSSA, Madison, Wisconsin, Pp. 450.

Michoud, J. P. (1991). A citizen's guide to understanding and monitoring lakes and streams. Washington state Dept or Ecology, Publication office Olympic W.A USA (360), 407 - 7472.

Mohammed, I. D., Kibon, A., Abbator, F. I. and Idris, K. K. (2001). Intake and digestion of three varieties of sorghum stover by sheep, proceedings of 6th annual conference of animal science association of Nigeria (ASAN), September 17-19, 2001, University of Maiduguri, Pp 142-144.

Mohammed, K. (1999). Historical background, In Adebayo, A. A. and Tukur, A. L. (ed) Adamawa State in Maps, Paraclete Publishers, Yola. Pp. 39 -84.

Moore, M. L. (1989). NALMS management guide for lakes and reservoirs. North American Lake Management
Society. P.O. Box 5443, Madison, WI, 5370554431 USA.

Morrison, G., Fatoki, O. S., Persson, L. and Ekberg, A. (2001). Assessment of the impact of point source pollution from the Keiskammahoek sewage treatment plant on the Keiskamma River - pH, electrical conductivity, oxygen - demanding substance and nutrients, Water SA. 27 (4), 475 - 480.

Nasrullah, M. N., Akhasi, R. and Kawamure, O. (2003). Nutritive Value of Forage Plants Grown in South Sulawesi, Indonesia". Asian-Australia Journal of Animal Science. 16: 693-701.

Ngele, M. B., Kalla, D. J. U., Abubakar, M., Dass, U. D. and Amba, A. A. (2008). Enhancing crop residues for livestock feeding in the tropics. Journal of league of researchers in Nigeria, 10 (2):1- 20.

Njidda, A. A. (2010). Chemical Composition, Fibre Fraction and Anti-Nutritional Substances of Semi-arid Browse Forages of North-Eastern Nigeria. Nigerian Journal of Basic and Applied Science, 18: 2: 181-188.

Njidda, A. A. Ikhimioya, I. and O. J. Babayemi (2010b).Variation of $24 \mathrm{~h}$ in vitro gas production and it relationship estimated metabolizable energy values of ruminant feeds. In: O. J. Babayemi, O. A. Abu, and E. O. Ewuola (eds.). Proc. of the 35th annual conference of Nig. Soc. For Anim. Prod. held on 14-17. March, 2010,University of Ibadan, Nigeria. Pp. 491 - 494.

Njidda, A. A. Ikhimioya, I., Muhammad, B. F. and Amaza, I. B. (2010a). Chemical Composition, fibre fraction and Anti- Nutritive Substances. In: O. J. Babayemi, O. A. Abu, and E. O. Ewuola (eds.). Proc. of the 35th annual conference of Nig. Soc. For Anim. Prod. held on 14-17. March, 2010,University of Ibadan, Nigeria. Pp. 477 - 480.

Norton, B. W. (1998). The nutritive value of tree legumes. In: Gutteridge, R.C., Shelton, H.M. (Eds.), Forage trees legumes in Tropical Agriculture. Tropical Grassland Society of Australia Inc., St Lucia Queensland, Pp. 15 - 48.

Norton, B. W. (2003). The Nutritive value of tree legumes. In: Gutteridge, R.C., Shelton, H.M. (Eds.), Forage trees legumes in Tropical Agriculture. Tropical Grassland Society of Australia Inc., St Lucia Queensland, Pp.1-10.

Odigure, J. O. and Adeniyi, O. D. (2001). Analysis of water quality in Minna metropolis. Journal of Engineering Technology and Industrial Applications, 2 (4): 98 108.

Okah, U., Okeke, C. N. and Anya, M. I. (2012) Intake and digestibility of dietary maize processing waste by West African dwarf (wad) sheep. Journal of Agricultural Technology 8(4): 1277-1284.

Okoli, I. C., Ebere, C. S., Emenalom, O. O., Uchegbu, M. C. and Esonu, B. O. (2001). Indigenous livestock 
production paradigms revisited. 111: An assessment of the proximate values of most preferred indigenous browses of Southeastern Nigeria. Anim. Prod. Invest., 4: 99-107.

Okoli, I. C., Maureen, O., Anunobi, O., Obua, B. E. and Enemuo, V. (2003). Studies on selected browses of southeastern Nigeria with particular reference to their proximate and some endogenous anti-nutritional constituents. Livestock Res. Rural Dev. 15 (9): 3 - 7.

Olajire, A. A. and Impekperia, F. E. (2000). A Study of Water quality of the Osun River; Metal Monitoring and Geochemistry. Bul!. Chem. Soc. Ethap. 14 (1):1 18.

Olalekan, A., Abubakar, B. and Abdul-Mumini, K. (2015). Physico - chemical characteristics of borehole water quality in Gassol Taraba state, Nigeria. African Journal of Environmental Science and Technology, 9(2): 143 - 154.

Omoniyi, L. A., Isah, O. A., Taiwo, O. O., Afolabi, A. D. and Fernandez, A. J. (2013). Assessment of Nutritive Value of some Indigenous Plants Consumed by Ruminants in the Humid and Sub-Humid Region of Nigeria using In Vitro Technique. The Pacific Journal of Science and Technology, 14 (1): 413 - 421.

Onaleye, K.J., Kibon, A., Mbahi, T. F. Mufwa, B. J. Gawi, G. O. and Labaran, H. A. (2012). Evaluation of five crop residues for degradability potentials in Goats at Jalingo, Taraba state. Journal of Science and Multidisciplinary Research, 4: 59 - 67.

Onwuka, C. F. I., Adetiloye, P. O. and Afolami, C. A. (1997). Use of household wastes and crop residues in small ruminant feeding in Nigeria. Technical Note, Small Ruminant Research, 24: 233-237.

Pellow, R. A. (1980). The production and consumption of Acacia browse and its potentials for animals protein. In: Browse in Africa., Le Houerou, H. N. ed. ILCA, Addis-Ababa Ethiopia, Pp. 223-231.

Pickering, K.T. and Owen, L. A. (1997). Introduction to Global Environmental Issues John Wiley: New York. Pp. $145-170$.

Ranjhnan, S. K. (2001). Animal Nutrition in the Tropics. 5th Edition. Vikas Publishing House: New Delhi, India. 593

Rittner, U. and Reed, J. D. (1992). Phenolics and In vitro degradability of protein and fiber in West African

\section{How to cite this article:}

Kubkomawa, I.H. C.C. Achonwa, U.E. Ogundu, I.C. Okoli, and Udedibie, A.B.I. 2017. Distribution and Proximate Compositions of Dry Season Browses in Adamawa State, North-Eastern Nigeria. Int.J.Curr.Res.Aca.Rev. 5(2), 7988. doi: http://dx.doi.org/10.20546/ijcrar.2017.502.011 browse. Journal of Sci. Food and Agriculture, 58: 21 28.

Saba, A. M. and Baba, A. H. (2004). Physico- chemical and bacteriological characterization of river Landzu, Bida, Nigeria. Proceedings of the 8th National Engineering Conference, Kaduna Polytechnic, Kaduna. Pp. 105 126.

Seyoum, B. and Zinash, S. (1989). The composition of Ethiopian feedstuffs, research report No. 6. institute of agricultural research (IAR), Addis Ababa, Ethiopia. Pp. 33.

Tijani, M. N., Onibalusi, S. O. and Olatunji, A. S. (2002). Hydro-chemical and Environmental Impact Assessment of Orita Aperin waste dumpsite, Ibadan, Southwestern Nigeria, Water resource. Journal of Nigerian Association of Hydrogeologists, 13: 78- 84.

Van Soest, P. J. (1982). Nutritional Ecology of the Ruminants, O and B Books. Inc. Oregon, USA.

Van Soest, P. J. (1988). Effect of environment and quality of fiber on the nutritive value of crop residues. In: J. D. Reed, B. S. Capper and P. J. H. Neate (eds.). Plant Breeding and Nutritive Value of Crop Residues. Proceedings of a Workshop Held at ILCA, Addis Ababa, Ethiopia, 7-10 December 1987. ILCA, Addis Ababa. Pp. 71- 96.

Van Soest, P. J. (1994). Nutritional Ecology of the Ruminant. Cornell University Press, Ithaca, New York, Pp. 476.

Van Soest, P. J., Robertson, J. B. and Lewis, B. A. (1991). Methods for dietary fiber, neutral detergent fiber and non-starch polysaccharides in relation to animal nutrition. Journal of Dairy Science, 74: 3583 - 3597.

WHO (1993). World Health Organization Report on Table Water Standard and Permissible Values.

Yitaye, A., Azage, T. and Mohammed, Y. K. (2001). Chemical composition and nutritive values of major feed resources in three peasant associations of Awassa Woreda, Southern Ethiopia. Proceedings of the 8th Annual Conference of the Ethiopian Society of Animal Production (ESAP) Held in Addis Ababa, Ethiopia, 24 -26 August 2000. Pp. 288 - 296. 